\title{
LIQUIDITY SHOCKS, EQUITY-MARKET FRICTIONS, AND OPTIMAL POLICY
}

\author{
Harris Dellas \\ University of Bern
}

Behzad Diba

Georgetown University

Olivier Loisel

CREST (ENSAE)

In this paper, we study the positive and normative implications of financial shocks in a standard New Keynesian model that includes banks and frictions in the market for bank capital. We show how such frictions influence materially the effects of bank liquidity shocks and the properties of optimal policy. In particular, they limit the scope for countercyclical monetary policy in the face of these shocks. A fiscal policy instrument can complement monetary policy by offsetting the balance-sheet effects of these shocks, and jointly optimal policies attain the same equilibrium that monetary policy (alone) could attain in the absence of equity-market frictions.

Keywords: Financial Shocks, Ramsey Optimal Monetary and Fiscal Policy, Banks

\section{INTRODUCTION}

The 2007-2009 financial crisis was the impetus for major changes in the practice of central banking, and in our models of monetary policy. ${ }^{1}$ The new models, understandably, focused mostly on analyzing the origins of this particular crisis or the policy responses that had already taken shape. Now, with the crisis hopefully behind us, it seems natural to ask how it has changed our understanding of stabilization policy and the role of banks in the transmission mechanism, during normal times. How are liquidity problems that affect the funding side of banks (say, in the interbank market) transmitted to the lending side, and what is the appropriate policy response? Is there an appropriate role for fiscal or quasi-fiscal policy tools (such as a capital infusion into the banking sector) during normal times?

The answers to these questions depend on what we assume about the presence and nature of frictions that banks face in debt and equity markets. The goals of

\footnotetext{
We want to thank Fabrice Collard, Nobu Kiyotaki, our discussants Philippe Bacchetta, Stelios Bekiros, Luisa Lambertini and Patrick Pintus, and two anonymous referees for valuable suggestions. This paper has previously circulated under the title "Financial Shocks and Optimal Policy." Address correspondence to: Olivier Loisel, ENSAE, Timbre J120, 3 Avenue Pierre Larousse, 92245 Malakoff Cédex, France; e-mail: olivier.loisel@ensae.fr; URL: http://www.cepremap.fr/membres/olivier.loisel.
} 
this paper are to make the role of such frictions transparent using a simple New Keynesian model with banks, and to highlight issues that we think remain to be addressed before we can move toward quantitative models of monetary policy with a banking sector.

It seems intuitive (and our model will illustrate) that a fiscal instrument allowing a cash infusion into banks can be a valuable policy tool if a friction in equity markets prevents banks from recapitalizing themselves. Absent such a friction, the funding and lending sides of banks are decoupled (in a model where the Modigliani-Miller theorem applies), and a "liquidity crunch" is harder to model. In this case, a simple model with no externalities or information asymmetries would tell us that stock holders will fund any lending projects that are worthwhile. And the case for policy intervention seems harder to make; in particular, a fiscal transfer to banks may simply induce them to pay more dividends, without altering their lending or other activities. ${ }^{2}$ Similarly, giving banks access to any frictionless source of funding (say, commercial paper) would suffice to decouple their funding and lending sides in a simple model.

The 2007-2009 crisis essentially shut down the funding side of banks in the interbank, securitization, and commercial-paper markets simultaneously. The sheer magnitude and breadth of the crisis apparently convinced policy makers that banks were not in a position to recapitalize themselves in equity markets. ${ }^{3}$ Gertler and Kiyotaki (2010) analyze the effects of shutting down the interbank market in a model with no market for bank equity. In their model — and in the models of Meh and Moran (2010), Gertler and Karadi (2011), and others-bankers have some personal net worth (they cannot issue equity) and face a borrowing limit due to an agency problem. This is why a liquidity crunch affects bank lending and has real effects in these models.

In this paper, we examine the implications of the standard New Keynesian model with banks that have access to equity finance but face frictions in adjusting their capital. ${ }^{4}$ The banks in our model issue equity, pay dividends, and maximize their stock-market value. Absent frictions in the equity market, it may be optimal to make the equity payout negative-which amounts to paying negative dividends (in the model) and corresponds to new equity issues (in reality)-under some realizations of shocks. To illustrate the role of an equity-market friction, we compare the frictionless model with the same model under the dividend-smoothing specification of Jermann and Quadrini $(2009,2012) .{ }^{5}$ This ad hoc feature allows us to show how optimal policy changes as we vary the smoothing parameter; but our model is not suitable for a quantitative exercise. We should note, on this front, that the other models we mentioned previously involve assumptions that are equivalent to our dividend-smoothing assumption. ${ }^{6}$ Gertler et al. (2012) provide an alternative framework in which the composition of the balance sheets of banks (equity vs. debt) plays a key role in the response of the economy to various shocks and also for the nature of optimal policy. In their model, banks can issue equity; but the agency problem that limits debt finance in Gertler and Kiyotaki (2010) also applies to equity finance in Gertler et al.'s (2012) setup. Again, this friction is equivalent to our dividend-smoothing assumption. 
For the specifications with and without dividend smoothing, we characterize the optimal (Ramsey) monetary policy as well as the optimal joint monetary and fiscal policy - where the latter takes the form of a direct transfer to banks - in the face of financial and other shocks. A (negative) liquidity shock causes an increase in the demand for bank reserves. The version of our model with a frictionless equity market has strong implications because it allows banks to recapitalize themselves easily. In this setting, the lending and borrowing sides of banks become decoupled. The spread between the lending rate and the risk-free (Consumption Capital Asset Pricing Model, henceforth CCAPM) rate does not depend on the liquidity shock. Furthermore, the decoupling of the lending and borrowing sides eliminates the need for fiscal intervention. In contrast, in the version of our model with an equity-market friction (dividend smoothing), a liquidity shock (modeled as an increase in the demand for excess reserves) increases the spread between the lending rate and the risk-free (CCAPM) rate and reduces the volume of loans. A fiscal cash infusion reduces the spread and increases the volume of loans. Indeed, in our model, the availability of a fiscal instrument serves precisely to undo the constraint that the equity-market friction imposes on optimal monetary policy. That is, optimal policy with the fiscal and monetary instruments under the equitymarket friction implements exactly the same equilibrium as optimal policy with only the monetary instrument under a frictionless equity market (in which case, the fiscal instrument is redundant). ${ }^{7}$

Two observations seem in order about modeling choices. First, for concreteness, we model our liquidity shock as an increase in demand for excess reserves. But we could make the same points in the context of any other shock that tightens bank funding. In particular, the points we make would also apply to shocks that hamper loan securitization or issuance of commercial paper. Second, we focus on comparing models with and without friction in the market for bank equity. But the relevant comparison is between a model in which all the markets that banks use to fund themselves have frictions and models in which there is at least one frictionless market. For example, a model in which there is no friction in the commercial-paper or securitization market is equivalent to our model with no financial friction - the funding and lending sides of bank are decoupled. This suggests that an attempt to build a more quantitative model of liquidity shocks would face the daunting task of calibrating frictions in all the markets that banks use for funding.

In what follows, Sections 2 and 3 present our model and the parameter values used for our simulations. Section 4 reports our results on Ramsey policy and comparisons with simple rules for monetary policy. In Section 5, we discuss perspectives from the existing literature that may offer a more structural alternative for our dividend smoothing assumption. Section 6 contains a brief summary and conclusions.

\section{MODEL}

We consider an economy populated with infinitely lived households, monopolistically competitive banks and firms producing differentiated intermediate goods, 
perfectly competitive firms producing the final good, and fiscal and monetary authorities. Our rendition of households and their demand for money is closely related to the standard Lucas and Stokey (1983) setup with cash goods and credit goods, often used in the normative literature [e.g., Chari et al. (1991); Correia et al. (2008)]. To incorporate a demand for deposits in the model, we assume that the consumption good is a Cobb-Douglas aggregate over a good that can be bought with cash and a good that can be bought using deposits. We let "leisure" implicitly serve as the credit good in our model.

Each period is divided into two subperiods: a financial exchange followed by a goods exchange. In the financial exchange, after the realization of current shocks, retailers borrow from banks to buy the intermediate goods and assemble the final good to be sold to consumers, the government, and banks (in the version of the model with costly banking); households pay taxes and choose their asset portfolios, acquiring the money and deposits that they plan to use in the subsequent goods exchange; and firms producing intermediate goods pay wages and dividends with the proceeds of their sales to retailers. In the goods exchange, households use money and deposits to buy goods from the retailers that have not been hit by a default shock (those who have been hit by the shock end up not producing anything). We assume that the government buys goods with cash (although this is inconsequential for our analysis). Retailers must wait until the following financial exchange to use the cash and liquidate the deposits that they acquire; so they are indifferent between these means of payment and set the same price for cash and deposit goods.

\subsection{Households}

The representative household gets utility from consumption and disutility from work,

$$
U_{t}=E_{t}\left\{\sum_{j=0}^{+\infty} \beta^{j}\left[\Phi \ln \left(c_{t+j}^{M}\right)+(1-\Phi) \ln \left(c_{t+j}^{D}\right)-\frac{1}{1+\chi} h_{t+j}^{1+\chi}\right]\right\},
$$

with $0<\beta<1,0<\Phi<1$, and $\chi>0$, where $c_{t}^{M}$ and $c_{t}^{D}$ denote consumption of cash goods and deposits goods at date $t$, respectively, and $h_{t}$ stands for hours worked (in the intermediate-goods sector).

The household's budget constraint, in real terms, is

$$
\begin{aligned}
& \left(\frac{1+R_{t-1}^{A}}{\Pi_{t}}\right) a_{t-1}+\left[\left(\frac{1+R_{t-1}^{D}}{\Pi_{t}}\right) d_{t-1}-\frac{c_{t-1}^{D}}{\Pi_{t}}\right]+\left(\frac{m_{t-1}^{H}}{\Pi_{t}}-\frac{c_{t-1}^{M}}{\Pi_{t}}\right) \\
& +w_{t} h_{t}+\pi_{t}^{I}+z_{t}-a_{t}-m_{t}^{H}-d_{t}-t_{t} \geq 0,
\end{aligned}
$$

where $\Pi_{t} \equiv P_{t} / P_{t-1}$ is the inflation rate, $d_{t}$ deposits, $1+R_{t}^{D}$ the gross nominal interest rate on deposits, $m_{t}^{H}$ money balances held by the household, $w_{t}$ wages, $\pi_{t}^{I}$ 
the profits of firms producing intermediate goods, $z_{t}$ the dividends paid by banks, and $t_{t}$ a lump-sum tax. The variables are represented by a lowercase letter when expressed in real terms and by an uppercase letter when expressed in nominal terms. The asset $a_{t}$ represents the household's portfolio of nominally risk-free bonds, and $1+R_{t}^{A}$ is the gross nominal CCAPM interest rate. Risk-free nominal bonds may be issued by the government, banks, or other households (although, in equilibrium, the latter will be in zero net supply). In our simple setup, securitization of loans (with banks absorbing any default cost) is equivalent to banks issuing risk-free bonds. So we can also include in $a_{t}$ any securitization of bank loans. ${ }^{8}$

The households' optimization problem is

$$
\operatorname{Max}_{a_{t}, c_{t}^{M}, c_{t}^{D}, m_{t}^{H}, d_{t}, h_{t}} U_{t}
$$

subject to the cash- and deposits-in-advance constraints

$$
\begin{gathered}
m_{t}^{H}-c_{t}^{M} \geq 0, \\
d_{t}-c_{t}^{D} \geq 0,
\end{gathered}
$$

and the budget constraint (1). The first-order conditions of this optimization problem are

$$
\begin{array}{r}
\frac{\Phi}{c_{t}^{M}}-\mu_{t}^{M}-\beta E_{t}\left\{\frac{\lambda_{t+1}}{\Pi_{t+1}}\right\}=0, \\
\frac{1-\Phi}{c_{t}^{D}}-\mu_{t}^{D}-\beta E_{t}\left\{\frac{\lambda_{t+1}}{\Pi_{t+1}}\right\}=0, \\
\mu_{t}^{M}+\beta E_{t}\left\{\frac{\lambda_{t+1}}{\Pi_{t+1}}\right\}-\lambda_{t}=0, \\
\mu_{t}^{D}+\beta\left(1+R_{t}^{D}\right) E_{t}\left\{\frac{\lambda_{t+1}}{\Pi_{t+1}}\right\}-\lambda_{t}=0, \\
-h_{t}^{\chi}+w_{t} \lambda_{t}=0, \\
\beta\left(1+R_{t}^{A}\right) E_{t}\left\{\frac{\lambda_{t+1}}{\Pi_{t+1}}\right\}-\lambda_{t}=0,
\end{array}
$$

where $\mu_{t}^{M}, \mu_{t}^{D}$, and $\lambda_{t}$ are the Lagrange multipliers associated with the cash-inadvance, deposits-in-advance, and budget constraints, respectively.

\subsection{Intermediate Goods Producers}

There is a unit mass of monopolistically competitive firms producing intermediate goods. Firm $j$ operates the production function

$$
x_{t}(j)=h_{t}(j) \exp \left(\eta_{t}^{p}\right)
$$


where $\eta_{t}^{p}$ is an exogenous productivity shock. We assume that firms set their prices à la Calvo.

\subsection{Final Goods Producers}

Producers of the final good-henceforth, "retailers"-are perfectly competitive. They use $x_{t}(j)$ units of each intermediate good $j \in[0,1]$ to produce $y_{t}$ units of the final good with

$$
y_{t}=\left[\int_{0}^{1} x_{t}(j)^{\frac{\varepsilon-1}{\varepsilon}} d j\right]^{\frac{\varepsilon}{\varepsilon-1}},
$$

where $\varepsilon>1$. We assume that each final-good firm is hit by a default shock with probability $\delta_{t}$. A firm hit by the default shock uses the inputs but does not produce any output. Assuming independent realizations across firms, total output is $\left(1-\delta_{t}\right) y_{t}$. As we elaborate in the following, our retailers will borrow from banks, and both parties observe the probability of default before they enter the loan contract. ${ }^{9}$

Intermediate good $j$ sells for the nominal price $P_{t}^{X}(j)$. We break the retailer's optimization problem into two parts. First, the cost minimization problem involves choosing $x_{t}(j)$ for all $j \in[0,1]$ to minimize

$$
\int_{0}^{1} P_{t}^{X}(j) x_{t}(j) d j,
$$

given $y_{t}$ and subject to the constraint imposed by the production function (3). This implies

$$
x_{t}(j)=\left[\frac{P_{t}^{X}(j)}{P_{t}^{X}}\right]^{-\varepsilon} y_{t},
$$

where

$$
P_{t}^{X} \equiv\left[\int_{0}^{1} P_{t}^{X}(j)^{1-\varepsilon} d j\right]^{\frac{1}{1-\varepsilon}}
$$

is the marginal (and average) cost of producing $y_{t}$.

Second, retailers must borrow from banks to buy intermediate goods: ${ }^{10}$

$$
\frac{P_{t}^{X}}{P_{t}} x_{t}=l_{t},
$$

where $P_{t}$ is the price of the final good. The zero-profit condition of retailers implies

$$
P_{t}=\left(1+R_{t}^{L}\right) P_{t}^{X}
$$

So $P_{t}$ is just a markup over the cost $P_{t}^{X}$ of acquiring the goods, and the markup factor is the interest rate on loans. The zero-profit condition of retailers has the following interpretation. A one-period entrant at time $t$ could borrow $L_{t}$, buy intermediate goods, and sell them for $P_{t} y_{t}$. Next period, the potential entrant 
would have exactly $P_{t} y_{t}=\left(1+R_{t}^{L}\right) L_{t}$ to pay off the bank loan, with no profit or loss.

\subsection{Banks}

Banks are owned by households and have some market power in setting the interest rates on deposits and loans. ${ }^{11}$ As in Gerali et al. (2010), this market power comes from monopolistic competition in the deposit market and the loan market. The representative final goods producer borrows a CES aggregate of differentiated loans, and the representative household holds a CES aggregate of differentiated deposits. Thus, a bank setting the gross nominal interest rate $1+R_{t}^{L}$ that it charges on its loans $l_{t}$ faces the demand curve

$$
l_{t}=\left(\frac{1+R_{t}^{L}}{1+\bar{R}_{t}^{L}}\right)^{-\gamma_{l}} \bar{l}_{t},
$$

where $\gamma_{l}>1$ is the exogenous elasticity of substitution between differentiated loans. Similarly, a bank setting the gross nominal interest rate, $1+R_{t}^{D}$, paid on its deposits, $d_{t}$, faces

$$
d_{t}=\left(\frac{1+R_{t}^{D}}{1+\bar{R}_{t}^{D}}\right)^{\gamma_{d}} \bar{d}_{t}
$$

where $\gamma_{d}>1$ is the exogenous elasticity of substitution between differentiated deposits. Gerali et al. (2010) derive these demand curves from the first-order condition for optimality of final goods producers' portfolio of differentiated loans and the first-order condition for optimality of households' portfolio of differentiated deposits. ${ }^{12}$ The variables with an upper bar $\left(\bar{d}_{t}, \bar{l}_{t}, \bar{R}_{t}^{D}, \bar{R}_{t}^{L}\right)$ denote the corresponding average variables. All banks are identical and set the same interest rates in a symmetric equilibrium.

Banks hold reserves $m_{t}^{B}$ to manage the liquidity of deposits:

$$
m_{t}^{B}=d_{t} \exp \left(\eta_{t}^{d}\right)
$$

where $\eta_{t}^{d}$ is an exogenous reserves demand shock. The representative bank chooses the amount of dividends $z_{t}$ and the amount of securities $a_{t}$ (both introduced in Subsection 2.1), as well as $m_{t}^{B}, R_{t}^{D}$, and $R_{t}^{L}$, to maximize its stock-market value

$$
E_{t}\left\{\sum_{j=0}^{+\infty} \beta^{j} \lambda_{t+j} z_{t+j}\right\}
$$


subject to (8)-(10), and the cash-flow constraint

$$
\begin{aligned}
z_{t} & =a_{t}+d_{t}+\left(1-\delta_{t-1}\right)\left(\frac{1+R_{t-1}^{L}}{\Pi_{t}}\right) l_{t-1}+\frac{1}{\Pi_{t}} m_{t-1}^{B} \\
& -\frac{\Phi_{a}}{2}\left(a_{t}-a^{*}\right)^{2}-\left(\frac{1+R_{t-1}^{A}}{\Pi_{t}}\right) a_{t-1}-\left(\frac{1+R_{t-1}^{D}}{\Pi_{t}}\right) d_{t-1} \\
& -l_{t}-m_{t}^{B}-\tau_{t}-\frac{\Phi_{z}}{2}\left(z_{t}-z^{*}\right)^{2},
\end{aligned}
$$

with $\Phi_{a} \geq 0$ and $\Phi_{z} \geq 0$, where $\delta_{t}$ is the default rate, and $\tau_{t}$ a tax (when positive) or transfer (when negative) financed by taxing households. To study the responses of endogenous variables to a fiscal transfer to banks, we set

$$
\tau_{t}=\tau_{s s}-\varepsilon_{t}^{\tau},
$$

where $\varepsilon_{t}^{\tau}$ is an exogenous shock and, for any variable $v_{t}, v_{s s}$ denotes the steady state value of $v_{t}$. Setting $\Phi_{a}=0$ leads to a standard setup with a frictionless market for nominally riskless debt or securitization. With $\Phi_{a}>0$, our banks face a cost of issuing an amount of securities $a_{t}$ different from $a^{*}$. In our simulations, $\Phi_{a}>0$ corresponds to the case where banks face increasing marginal costs of borrowing (or securitizing) amounts above $a^{*}$. This is a smooth version of the borrowing limit implied by the agency problem in the models of Gertler and Kiyotaki (2010), Meh and Moran (2010), Gertler and Karadi (2011), and Gertler et al. (2012). ${ }^{13}$ When $\Phi_{z}>0$, banks face a cost of setting dividends different from $z^{*}$. In our simulations, $\Phi_{z}>0$ corresponds to the case where paying dividends below $z^{*}$ hurts the stock-market value of banks.

In a symmetric equilibrium, the first-order conditions of this maximization problem are

$$
\begin{aligned}
\lambda_{t}-\lambda_{t}^{z}\left[1+\Phi_{z}\left(z_{t}-z^{*}\right)\right] & =0, \\
\lambda_{t}^{z}\left[1-\Phi_{a}\left(a_{t}-a^{*}\right)\right]-\beta\left(1+R_{t}^{A}\right) E_{t}\left\{\frac{\lambda_{t+1}^{z}}{\Pi_{t+1}}\right\} & =0, \\
\left(\frac{1+R_{t}^{L}}{1+R_{t}^{A}}\right)\left[1-\Phi_{a}\left(a_{t}-a^{*}\right)\right]\left(1-\delta_{t}\right)-\frac{\gamma_{l}}{\gamma_{l}-1} & =0, \\
\frac{1-\Phi_{a}\left(a_{t}-a^{*}\right)}{1+R_{t}^{A}}-1+\frac{\lambda_{t}^{d}}{\lambda_{t}^{z}} & =0, \\
\left(\frac{1+R_{t}^{D}}{1+R_{t}^{A}}\right)\left[1-\Phi_{a}\left(a_{t}-a^{*}\right)\right]-\frac{\gamma_{d}}{\gamma_{d}+1}\left(1-\eta_{t}^{d} \frac{\lambda_{t}^{d}}{\lambda_{t}^{z}}\right) & =0,
\end{aligned}
$$

where $\lambda_{t}^{d}$ and $\lambda_{t}^{z}$ are the Lagrange multipliers associated with equations (10) and (11), respectively. Note that there is a monopoly markup on the lending rate and 
a monopoly "markdown" on the deposit rate. Note also that the risk premium, which is determined by equation (15), depends positively on the default rate and, in the presence of equity market frictions $\left(\Phi_{a}>0\right)$, on banks' marginal cost of issuing risk-free securities.

\subsection{Fiscal and Monetary Authorities}

Government purchases $g_{t}$ are exogenous and follow an AR(1) process. For concreteness, we assume that the fiscal authority uses cash to pay for its purchases,

$$
m_{t}^{G}=g_{t}
$$

but this does not matter for our results. Because Ricardian equivalence holds in our model, we do not need to model the dynamics of public debt explicitly. ${ }^{14} \mathrm{We}$ can just assume that the fiscal authority maintains a balanced budget and sets

$$
t_{t}=g_{t}-\tau_{t}
$$

When we consider the model under a simple monetary policy rule (i.e., when we conduct our positive analysis), we will use a rule such as

$$
\left(1+R_{t}^{A}\right)=\left(1+R_{t-1}^{A}\right)^{\rho}\left[\left(1+R_{s s}^{A}\right)\left(\frac{\Pi_{t}^{X}}{\Pi_{s s}}\right)^{\theta_{m}}\right]^{1-\rho}
$$

where $\Pi_{t}^{X} \equiv P_{t}^{X} / P_{t-1}^{X}, 0 \leq \rho<1$, and $\theta_{m}>1$ (to ensure local equilibrium determinacy), or the equivalent rule reacting to CPI inflation. The monetary authority sets the interest rate $R_{t}^{A}$ according to one of these rules, and adjusts money supply $m_{t}$ to clear the money market at this interest rate. In our normative analysis, we will compare these rules with optimal (Ramsey) policy.

\subsection{Market Clearing Conditions}

The goods market clearing condition is

$$
\left(1-\delta_{t}\right) y_{t}=c_{t}+g_{t}+\frac{\Phi_{a}}{2}\left(a_{t}-a^{*}\right)^{2}+\frac{\Phi_{z}}{2}\left(z_{t}-z^{*}\right)^{2},
$$

and the money market clearing condition is

$$
m_{t}=m_{t}^{H}+m_{t}^{B}+m_{t}^{G}
$$




\subsection{Shock Processes}

We assume that $\varepsilon_{t}^{\tau}$ is a white noise (with standard deviation $\sigma_{\tau}$ ) and that the other shocks follow autoregressive processes of order one:

$$
\begin{aligned}
\eta_{t}^{p} & =\rho_{p} \eta_{t-1}^{p}+\varepsilon_{t}^{p}, \\
\log \left(g_{t}\right) & =\left(1-\rho_{g}\right) \log \left(g_{s s}\right)+\rho_{g} \log \left(g_{t-1}\right)+\varepsilon_{t}^{g}, \\
\eta_{t}^{d} & =\left(1-\rho_{d}\right) \eta_{s s}^{d}+\rho_{d} \eta_{t-1}^{d}+\varepsilon_{t}^{d}, \\
\log \left(\delta_{t}\right) & =\left(1-\rho_{\delta}\right) \log \left(\delta_{s s}\right)+\rho_{\delta} \log \left(\delta_{t-1}\right)+\varepsilon_{t}^{\delta},
\end{aligned}
$$

where $\rho_{p}, \rho_{g}, \rho_{d}$, and $\rho_{\delta}$ are parameters between zero and one, whereas $\varepsilon_{t}^{p}, \varepsilon_{t}^{g}$, $\varepsilon_{t}^{d}$, and $\varepsilon_{t}^{\delta}$ are white noises (with standard deviations $\sigma_{p}, \sigma_{g}, \sigma_{d}$, and $\sigma_{\delta}$ ).

\subsection{Frictionless Equity Market}

The special case of our model with a frictionless equity market $\left(\Phi_{z}=0\right)$ has a number of strong implications. In this case, (13) implies $\lambda_{t}=\lambda_{t}^{z}$. Then, combining (14) with (2), we see that the marginal cost of borrowing (or securitization) is zero. If we set $a^{*}=0$ (so that any borrowing or securitization is costly), banks will not borrow or issue securities. Note that this implication is not due to the functional forms we assume for costs. The more general point is that banks should not undertake costly borrowing or securitization if they can issue equity (freely adjust dividends), get funds at the CCAPM rate from their owners, and save the costs of borrowing or securitization.

Also, in this case, (15) implies that the spread between the lending rate and the risk-free (CCAPM) rate fluctuates only in response to default shocks. Moreover, in this case, the lump-sum tax or transfer $\tau_{t}$ has no effect, except on the banks' dividend payments $z_{t}$. All these implications of the model are removed once we allow for a friction in the equity market $\left(\Phi_{z}>0\right)$.

\section{PARAMETERIZATION}

Our model has a number of parameters that are hard to calibrate. These parameter values do not play an important role in our results because our presentation will highlight qualitative features of optimal policies. ${ }^{15}$ Most importantly, we do not have any strong priors for setting our dividend-smoothing parameter $\Phi_{z}$. Jermann and Quadrini $(2009,2012)$ provide three different values, ranging from essentially 0 to 0.46 , for the U.S. nonfinancial business sector (using the same data set starting in the 1980s but three different approaches to estimation or calibration). We will set $\Phi_{z}=0.25$ in our benchmark model (allowing for dividend smoothing by banks). We will also set $\Phi_{a}=0.25$ in our benchmark model. These are arbitrary choices, and our discussion will compare the benchmark model with an alternative model setting $\Phi_{z}=\Phi_{a}=0 .{ }^{16}$ The default rate is $0.86 \%$ in the steady state (the average 
charge-off rate for U.S. bank loans from 1985Q1 to 2008Q3). We set $\Phi=0.43$ as the share of cash goods in consumption, following Chari et al. (1991). Given this value, the model pins down the steady state level of deposits and their share in funding bank loans.

We set $a^{*}=a_{s s}$ and treat it as securitization. Banks securitize $19 \%$ of their loans in the steady state (the ratio of securitized consumer and real estate loans to bank credit, for U.S. commercial banks, in August 2008). We assume that bank reserves are $7.6 \%$ of deposits in the steady state (the ratio of aggregate reserves of depository institutions to deposits in the United States in August 2008, where deposits are measured as M1 minus currency outside banks). The bank's balance sheet identity then pins down the value of $z_{s s}$. We set $z^{*}=z_{s s}$. We set $\gamma_{d}$ to make the interest rate on deposits $2 \%$ per annum. We set $\gamma_{l}$ to make the interest rate on loans $8.4 \%$ per annum (so, adjusting for the default rate, our prime rate would be $5 \%$ per annum, close to the average prime rate after 1980). In our simple rule for monetary policy, we set the inertia parameter to 0.8 and the (long-run) response to inflation to 1.5. Finally, we set the steady-state gross inflation rate per quarter to its optimal value, equal to 0.9996 . We explain later how this value is obtained and comment upon it.

The standard deviations of our shocks to productivity and government purchases take standard values. Our tax shock (fiscal transfer to the banking sector) is only for illustrative purposes and its size does not matter for our analysis. ${ }^{17}$ For each shock following an AR(1) process, we set the inertia parameter equal to 0.9.

We set the standard deviation of our default shock innovation so that an increase in the charge-off rate of the magnitude observed during the recent financial crisis would occur on the average once in 80 years in our model. In the data, the average charge-off rate from 1985Q1 to 2008Q3 was $0.86 \%$; the rate grew to $2.88 \%$ in 2009Q3. Under our parameterization, an increase of this magnitude over four quarters has probability 1/320, given our AR(1) process and assuming that the innovation has a Gaussian distribution. ${ }^{18}$ So a randomly selected quarter may be the start of a large four-quarter increase in the default rate on the average every 320 quarters or 80 years, which roughly corresponds to the time elapsed between the Great Depression and the recent crisis.

Similarly, we set the standard deviation of the reserves demand shock innovation so that, starting from its steady-state value of 7.6\% (the August 2008 figure), the reserves-to-deposits ratio reaches at least 107\% (the August 2009 figure) in one year's time with probability $1 / 320$.

The parameter values are shown in Table 1.

\section{NUMERICAL RESULTS}

We used Michel Juillard's software Dynare to log-linearize and simulate our model. ${ }^{19}$ We solved for the optimal (Ramsey) policy using Dynare and the program Get Ramsey developed by Levin and López-Salido (2004). The optimal steady state rate of inflation in our model has to strike a balance between two forces, 
TABLE 1. Calibration

\begin{tabular}{|c|c|c|}
\hline Parameter & Description & Value \\
\hline \multicolumn{3}{|c|}{ Preferences } \\
\hline$\beta$ & Discount factor & 0.99 \\
\hline$\chi$ & Inverse of Frisch elasticity of labor supply & 1 \\
\hline$\Phi$ & Share of cash goods in consumption & 0.43 \\
\hline \multicolumn{3}{|c|}{ Technology } \\
\hline$\gamma$ & Elasticity in the goods aggregator & 7 \\
\hline \multicolumn{3}{|c|}{ Nominal rigidities } \\
\hline \multicolumn{3}{|c|}{ Banking aspects } \\
\hline$\gamma_{d}$ & Elasticity in the deposits aggregator & 230 \\
\hline$\gamma_{l}$ & Elasticity in the loans aggregator & 420 \\
\hline$\Phi_{a}$ & Adjustment-cost parameter for securities & 0 or 0.25 \\
\hline$\Phi_{z}$ & Adjustment-cost parameter for dividends & 0 or 0.25 \\
\hline \multicolumn{3}{|c|}{ Monetary policy } \\
\hline$\rho$ & Degree of inertia in interest-rate rule & 0.8 \\
\hline$\theta_{m}$ & Coefficient on inflation in interest-rate rule & 1.5 \\
\hline \multicolumn{3}{|c|}{ Steady-state values } \\
\hline$\pi_{s s}$ & S.-s. gross inflation rate per quarter & 0.9996 \\
\hline$\delta_{s s}$ & S.-s. default rate per quarter & 0.0086 \\
\hline$\eta_{s s}^{d}$ & S.-s. reserve ratio & 0.076 \\
\hline$\frac{g_{s s}}{\left(1-\delta_{s s}\right) y_{s s}}$ & S.-s. share of government purchases in output & 0.25 \\
\hline & S.-s. ratio of bank borrowing (securities) to loans & 0.19 \\
\hline$\tau_{s s}^{l_{s s}}$ & S.-s. lump-sum tax on banks & 0 \\
\hline \multicolumn{3}{|c|}{ Shock processes } \\
\hline$\rho_{p}$ & Inertia in productivity shock & 0.9 \\
\hline$\rho_{g}$ & Inertia in government-expenditures shock & 0.9 \\
\hline$\rho_{d}$ & Inertia in shock to demand for reserves & 0.9 \\
\hline$\rho_{\delta}$ & Inertia in default shock & 0.9 \\
\hline$\sigma_{p}$ & Stand. dev. of productivity shock innovation & 0.0086 \\
\hline$\sigma_{g}$ & Stand. dev. of govt.-expenditures shock innovation & 0.010 \\
\hline$\sigma_{d}$ & Stand. dev. of reserves-demand shock innovation & 0.56 \\
\hline$\sigma_{\delta}$ & Stand. dev. of default shock innovation & 0.26 \\
\hline$\sigma_{\tau}$ & Stand. dev. of fiscal transfer to banks & 0.010 \\
\hline
\end{tabular}

as Khan et al. (2003) point out in the context of their model with a monetary friction and price rigidity. First, because a positive nominal interest rate distorts the household's labor-leisure decision, optimal policy would follow the Friedman Rule-a deflationary policy keeping the nominal interest rate equal to zero-if prices were fully flexible. Second, price rigidity, by itself, would call for price stability-keeping the inflation rate equal to zero-if there were no monetary distortion (as in standard NK models). In our model—as in several earlier models 

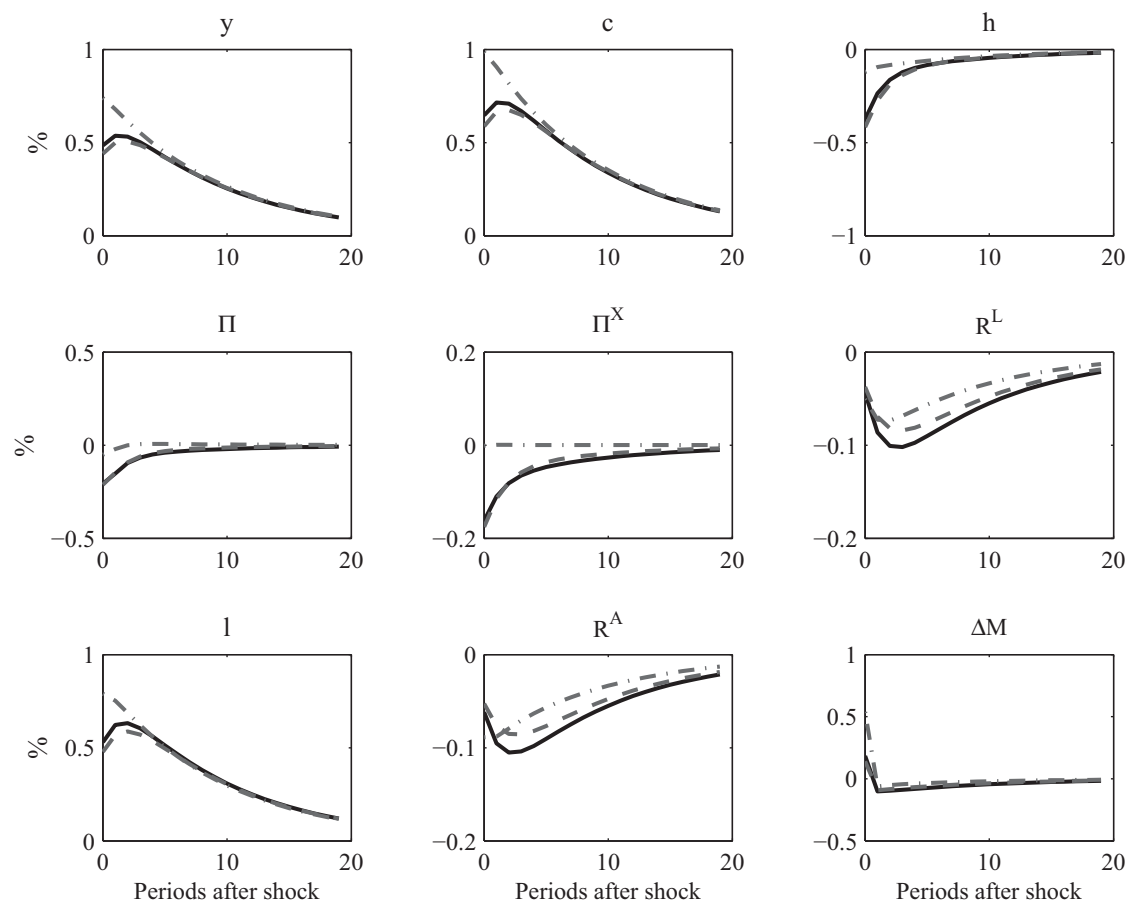

- Simple rule reacting to $\Pi---$ Simple rule reacting to $\Pi^{\mathrm{X}},-\cdot-$, Optimal monetary policy

FIGURE 1. Responses to productivity shock.

such as Khan et al. (2003)_optimal steady state inflation is close to zero; so the normative force calling for price stability dominates the monetary frictions that call for the Friedman Rule. ${ }^{20}$

\subsection{Benchmark Model}

Figures 1-3 display the impulse-response functions (IRFs) of selected variables in response to shocks in our benchmark model with $\left(\Phi_{a}, \Phi_{z}\right)=(0.25,0.25)$ (i.e., in the presence of equity market frictions). Each figure shows the responses under our two simple rules, reacting to the inflation measures $\Pi$ and $\Pi^{X}$, and under optimal (Ramsey) monetary policy. We do not optimize over the fiscal instrument (we set the transfer equal to zero) for the results reported in these figures.

The solid lines show the IRFs under a simple rule reacting to CPI inflation (П). The responses to familiar shocks (in Figures 1 and 2) are in accordance with conventional wisdom. A positive productivity shock raises output and lowers inflation. A positive government-expenditures shock raises output, lending, inflation, and interest rates, but decreases private consumption because of the 


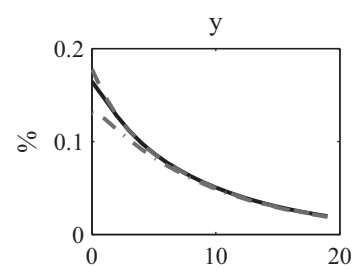

П

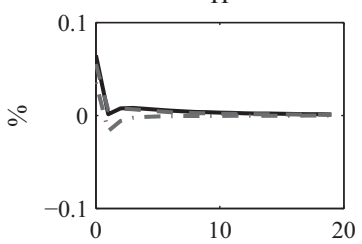

1

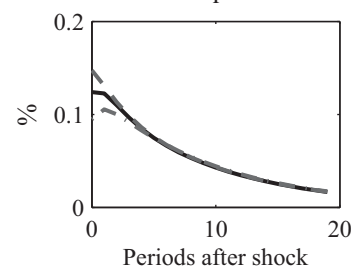

$\mathrm{c}$

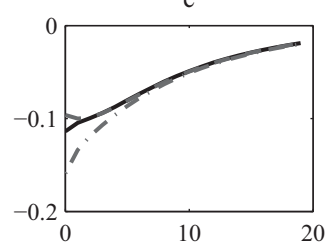

$\Pi^{\mathrm{X}}$

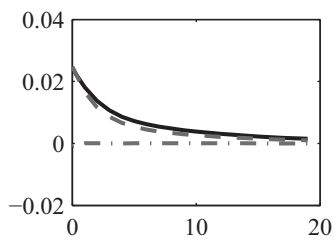

$\mathrm{R}^{\mathrm{A}}$

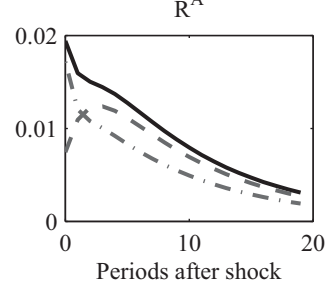

h

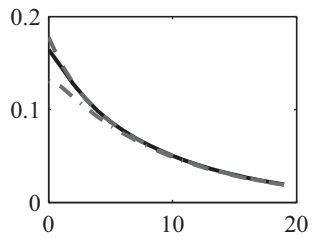

$\mathrm{R}^{\mathrm{L}}$

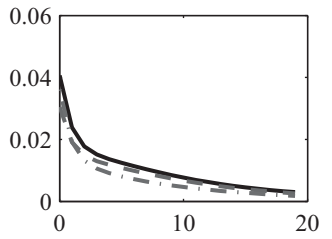

$\Delta \mathrm{M}$

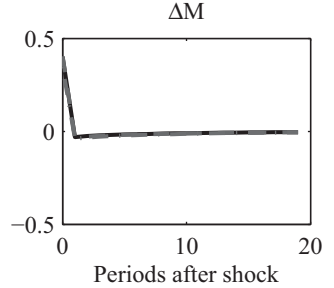

- Simple rule reacting to $\Pi---$ Simple rule reacting to $\Pi^{\mathrm{X}} \cdot-\cdot-$ - Optimal monetary policy

FIGURE 2. Responses to government-expenditures shock.

familiar Ricardian effect. Following a positive shock to the demand for reserves (Figure 3), output, hours, private consumption, and lending decrease, while inflation and interest rates rise.

Why is an increase in the demand for reserves inflationary in our model? When banks need more reserves, their balance sheets tighten and they want to lend less. Lending rates rise and the associated cost increases the price of final goods. The higher prices curb aggregate demand and reduce consumption, output, and hours. These effects, and the effect on prices of intermediate goods, however, are fairly small. ${ }^{21}$ The responses in Figure 3 illustrate that shocks to demand for reserves work like adverse supply shocks in our model.

The direct positive effect of the lending rate on inflation comes from the presence of a cost channel in our model (more specifically, from our assumption that final goods producers borrow from banks to buy intermediate goods, so that variations in the lending rate affect their cost of production). Barth and Ramey (2001) and Ravenna and Walsh (2006) provide empirical evidence, based on industry-level and aggregate data, that is suggestive of a direct positive interest-rate effect on inflation through a cost channel. And several DSGE models incorporate a cost channel by 

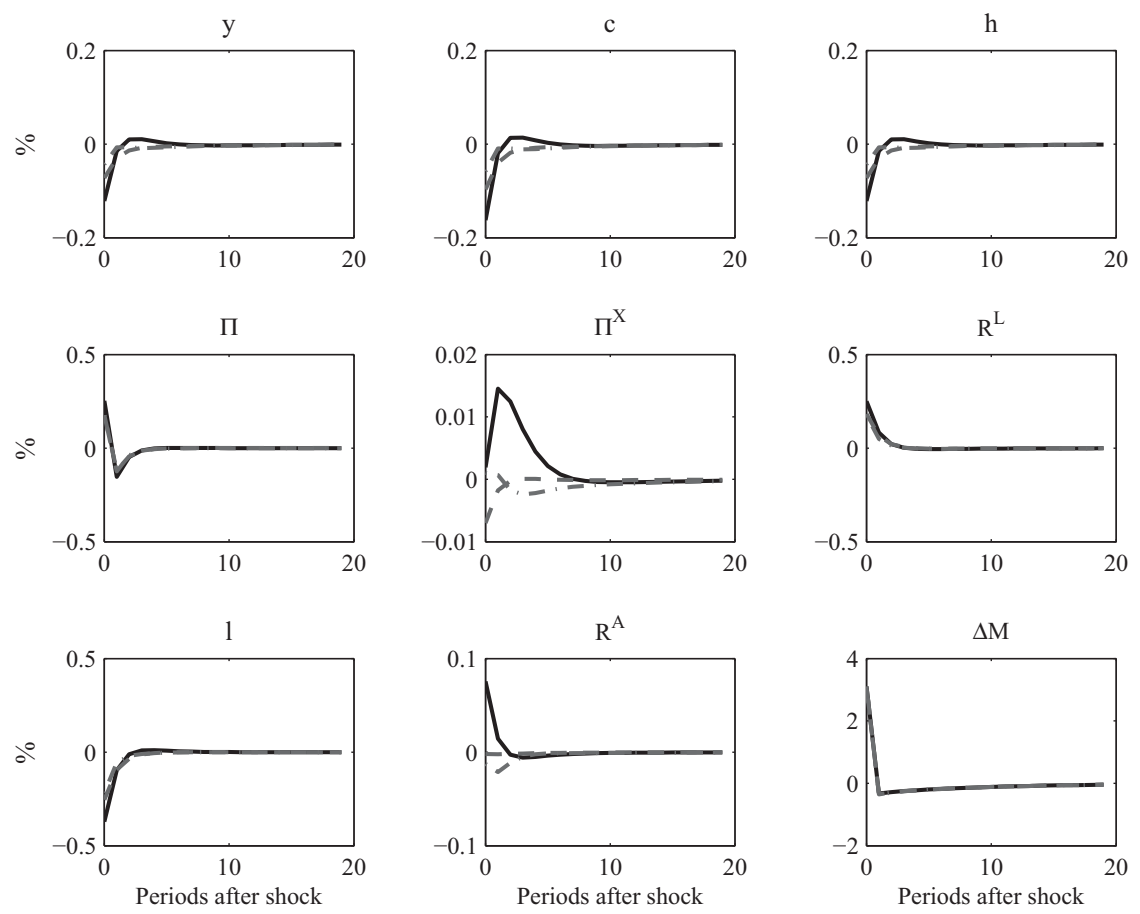

- Simple rule reacting to $\Pi---$ Simple rule reacting to $\Pi^{\mathrm{X}},-,-$. Optimal monetary policy

FIGURE 3. Responses to shock to demand for reserves.

assuming that firms must pay (at least part of) their factors of production before they receive revenues from sales, and must borrow to finance these payments [e.g., Christiano et al. (2005) and Ravenna and Walsh (2006)]. ${ }^{22}$

Our stylized model may well overstate some consequences of a simple rule that reacts to CPI inflation. In the model, banks raise the lending rate when they are less eager to lend and retailers pass on the cost of borrowing to consumers right away (there is no rigidity in retail prices). So the CPI inflation rate in our model is quite sensitive to financial shocks. If monetary policy responds to this measure of inflation, then the effects of shocks on endogenous variables also reflect the resulting changes in the policy stance. The dashed lines in Figures 1-3 show the corresponding IRFs assuming that the simple monetary rule responds to inflation in the price index for intermediate goods $\left(\Pi^{X}\right)$, as specified in (16). Because $\Pi^{X}$ is less sensitive to financial shocks, these IRFs do not reflect endogenous monetary responses as much as the solid lines (the IRFs under the simple rule responding to CPI inflation) do. Also, the conventional wisdom of NK models linking optimal policy to inflation targeting applies more naturally to our simple rule reacting to inflation in the price index for intermediate goods, $\Pi^{X}$. 
The lines that are both dashed and dotted show the IRFs under optimal (Ramsey) monetary policy. In Figure 1, optimal policy allows somewhat larger increases in output and consumption and opts for a smaller decrease in inflation than our simple rule targeting CPI inflation. In particular, optimal policy essentially keeps inflation in the price index for intermediate goods unchanged but tolerates some volatility in CPI inflation. This property is due to the fact that the CPI, unlike intermediate goods inflation, is affected through the cost channel. And we know from Ravenna and Walsh (2006) that the presence of a cost channel introduces a trade-off between output and price stability. Note that optimal policy also keeps $\Pi^{X}$ closer to zero in response to a shock to government purchases (Figure 2).

Following a shock that increases the demand for reserves, optimal policy (Figure 3) allows output, consumption, labor hours, and lending to fall. To bring about the decrease in the volume of loans as an equilibrium outcome, lending rates must rise; and this increases CPI inflation. Optimal policy cuts the policy rate (slightly) and allows a large monetary expansion in response to the increase in demand for reserves. The optimal monetary expansion is reminiscent of Poole's (1970) analysis of how policy should respond to money-demand shocks in the IS-LM model.

Compared with optimal policy, our simple rule responding to CPI inflation tolerates much larger contractions in output, consumption, and hours when the demand for reserves increases. The difference arises from the fact that the simple rule raises the policy rate to fight inflation, whereas optimal policy cuts the policy rate to moderate the contraction. Once again, the simple rule reacting to $\Pi^{X}$ comes closer to optimal policy.

We calculate the welfare losses from simple rules relative to optimal policy and express these welfare losses as consumption equivalents, following Lucas (2003). The computed welfare losses are quite small. For instance, the rule involving a response to inflation in the price index for intermediate goods entails a welfare loss of only $0.03 \%$ compared to optimal policy. That is, augmenting consumption by $0.03 \%$ each period would be enough to compensate consumers for living under the simple rule, instead of having the fully optimal policy in effect. In this sense, the normative punchline of simple NK models applies to our model: a simple rule that stabilizes the "right" measure of inflation is optimal, or very close to optimal.

Given that our simple rule reacting to $\Pi^{X}$ comes so close to optimal policy (has a welfare loss of $0.03 \%$ of consumption), we do not explore the possibility that another rule (perhaps reacting to the welfare-relevant output gap) performs even better. We can, however, identify rules that do quite poorly. One example is a commonly used version of a Taylor rule with values of 0.8 for the inertia parameter, 1.5 for the long-run response to CPI inflation, and 0.5 for the long-run response to the output gap relative to the steady state. The welfare cost of using this policy is $0.58 \%$ of consumption each period. We also consider a rule that sets an almost constant growth rate for the money supply. ${ }^{23}$ The welfare cost of this policy is $1.26 \%$ of consumption per period. This is not surprising: as we saw previously, optimal policy allows money growth to fluctuate considerably 

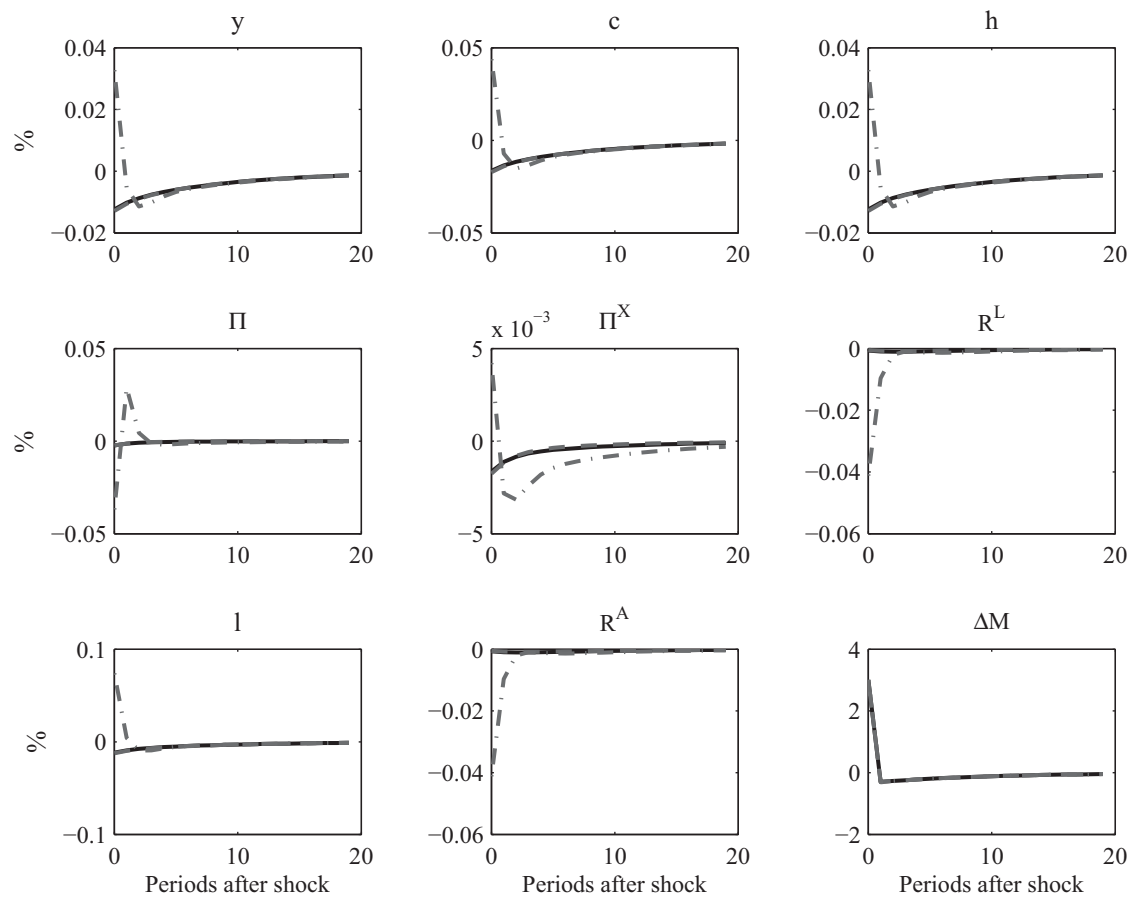

- Simple rule reacting to $\Pi--$ Simple rule reacting to $\Pi^{\mathrm{X}},-,-$, Optimal monetary policy

FIGURE 4. Responses to shock to demand for reserves in the absence of equity market frictions.

in response to liquidity shocks in our model. A money supply rule hinders such optimal variation in the money supply and can lead to significant welfare losses [as discussed by Collard and Dellas (2005)].

\subsection{Frictionless Equity Market}

Although the preceding results from our benchmark model mostly accord with familiar views, we obtained these results by setting $\Phi_{a}=\Phi_{z}=0.25$. What happens if we set $\Phi_{a}=\Phi_{z}=0$, instead? The optimal responses to shocks to productivity and government purchases do not change. Optimal responses to our liquidity shock (increase in demand for reserves), however, change when we remove the equity-market friction (Figure 4). First of all, compared to Figure 3, the contractionary effects of this liquidity shock on output, consumption, and hours are an order of magnitude smaller. In Figure 3 (with the equity-market friction) the contraction reflected the increase in bank lending rates in response to tighter balance sheet conditions. In Figure 4 (without the equity-market friction), balance 

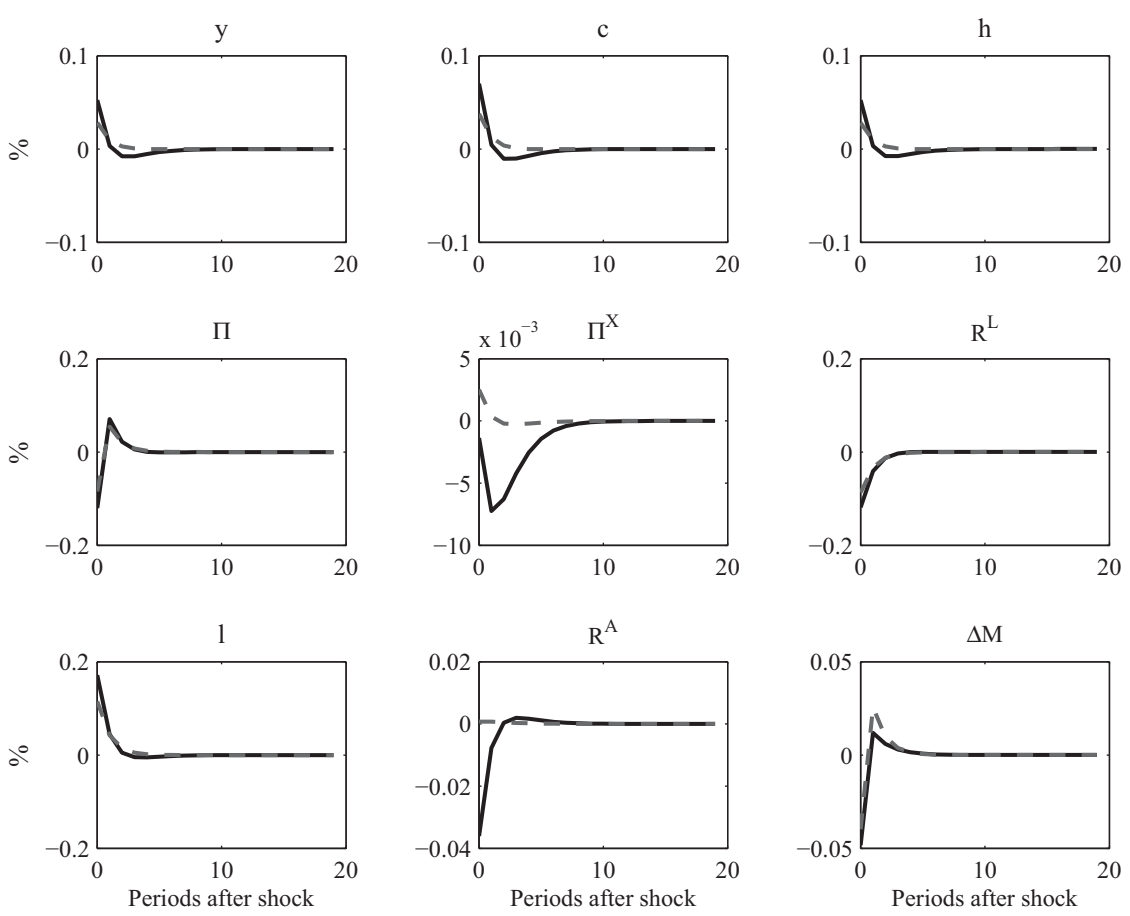

Simple rule reacting to $\Pi \quad-\quad-$ Simple rule reacting to $\Pi^{\mathrm{X}}$

FigURE 5. Responses to fiscal transfer to banks.

sheet conditions do not play a role, and lending rates actually fall by a small amount. ${ }^{24}$ In this case, the increase in money demand has the familiar (but small) deflationary effect. ${ }^{25}$

As we pointed out earlier (based on the relevant first-order conditions), banks do not engage in costly securitization (or borrowing) if they have access to funds in a frictionless equity market. If we set $\Phi_{z}=0$ and $\Phi_{a}>0$, our model implies that $a_{t}=a^{*}$. And if we set $\Phi_{z}>0$ and $\Phi_{a}=0$, our banks adjust $a_{t}$ in response to the liquidity shock.

\subsection{The Fiscal Instrument}

As we noted earlier, a fiscal transfer to banks has no effect in the absence of the equity-market friction-it is simply paid out as dividends. To provide some intuition for the potential role of fiscal policy in the presence of funding frictions, Figure 5 shows the effects of a fiscal transfer to banks, reducing $\tau$ in (12) from its steady state value of 0 to -0.01 . This transfer increases the banks' cash flow 

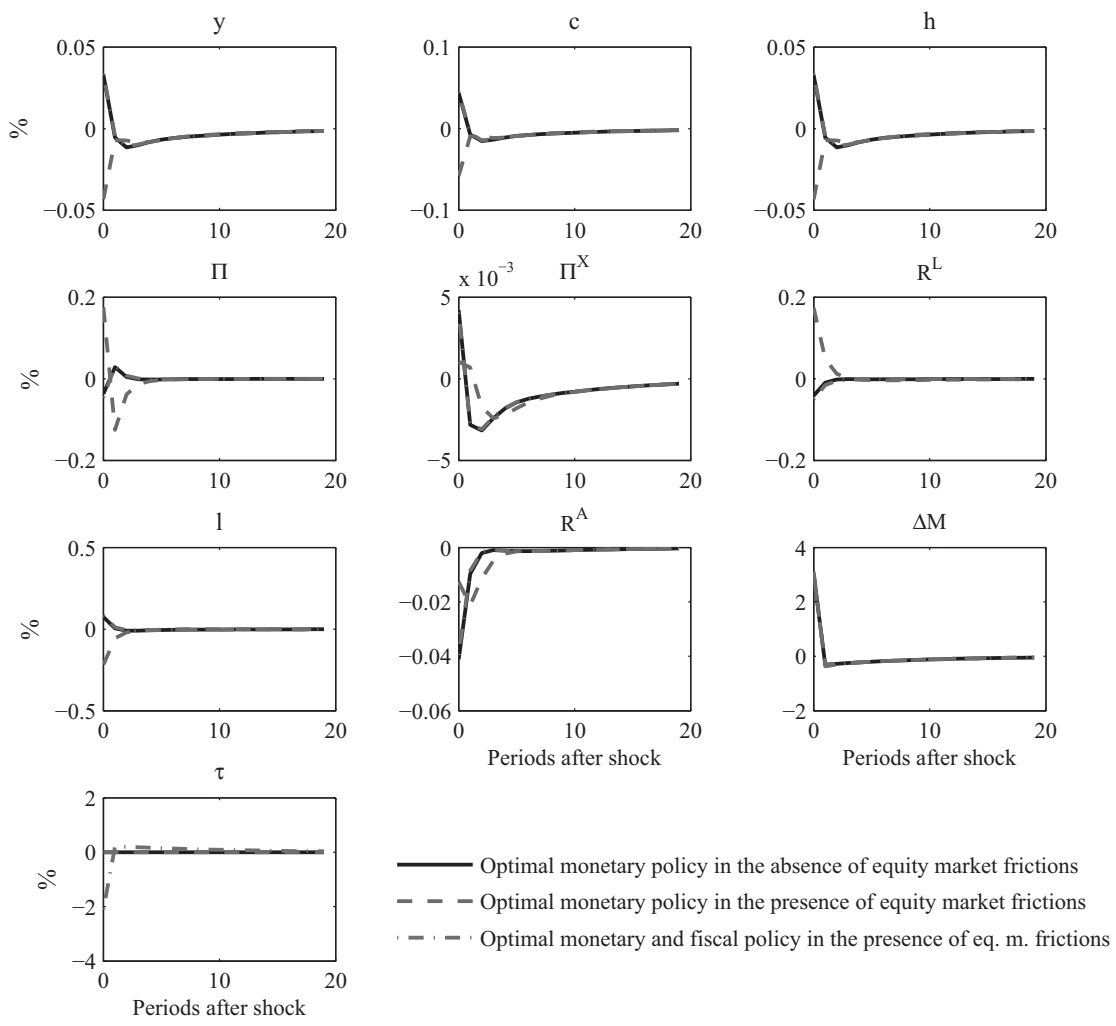

FIGURE 6. Responses to shock to demand for reserves.

and makes them more willing to lend. So they cut the interest rate on loans, which reduces consumer prices upon impact and stimulates spending.

We consider again optimal policy under funding frictions, with $\Phi_{a}=\Phi_{z}=$ 0.25 , but this time assume that the fiscal instrument can be used in addition to monetary policy. Optimal policy makes a transfer to banks when the demand for reserves increases. This shock also calls for a monetary response. In Figure 6, this monetary response and the responses of other variables virtually coincide with the ones under optimal monetary policy in the absence of a friction in the equity market. For example, under jointly optimal policies, there is a small increase in output, as is the case under optimal monetary policy in the frictionless model. In contrast, lacking the fiscal instrument, optimal monetary policy has to tolerate a decrease in output when there is a friction in the equity market. These findings are intuitive. The fiscal instrument is essentially used to offset the friction in the equity market, and optimal monetary policy opts for essentially the same solution that it would choose in the absence of this friction. 
The basic message of this subsection —and, more generally, of the paper-is left unchanged when the analysis is broadened to other kinds of bank liquidity shocks. All kinds of liquidity shocks will have essentially the same qualitative-positive and normative-implications, because in the presence of equity-market frictions they will tighten banks' balance sheets (i.e., make banks choose between cutting loans and cutting dividends) in the same way. Suppose, for instance, that banks now face the cost $\frac{\Phi_{a}}{2}\left[a_{t}-a^{*} \exp \left(-z_{t}^{s}\right)\right]^{2}$ of issuing an amount of securities $a_{t}$, where $z_{t}^{s}$ is a shock to the costs of securitization. Under optimal monetary policy, this shock will have essentially the same qualitative effects (not reported here) as the reserve-demand shock. ${ }^{26}$ And under jointly optimal fiscal and monetary policies, the fiscal instrument will again be used to offset the friction in the equity market, whereas optimal monetary policy will again opt for the same solution that it would choose in the absence of this friction. The only difference is that the optimal monetary policy response to a securitization-cost shock will be passive in the absence of frictions. Indeed, as we pointed out earlier (based on the relevant first-order conditions), banks will not engage in costly securitization if they have access to funds in a frictionless equity market, so that shocks to securitization costs will play no role in this case. Therefore, the optimal policy response to an increase in securitization costs in the presence of frictions (not reported here) will be purely fiscal, and this fiscal response will exactly offset the effects of the shock (as a fiscal transfer from households to banks saves households the resource cost of the securitization shock).

\section{STRUCTURAL INTERPRETATIONS}

In our model, the positive and normative implications of liquidity shocks (shocks that increase the demand for bank reserves) depend critically on the presence of funding frictions that banks face in the debt and equity markets. The friction we considered in the debt (or securitization) market is a smooth version of the debt limit that, following Kiyotaki and Moore (1997), is often used to pin down the financial structure of firms (or banks). ${ }^{27}$ Gertler and Kiyotaki (2010), Meh and Moran (2010), and Gertler and Karadi (2011), among others, develop models in which this agency problem puts a lower bound on the banks' capital ratio (the ratio of bank capital to loans). These contributions assume that banks cannot issue equity. So the lower bound on the capital ratio and the evolution of the bankers' personal net worth pin down the banks' financial structure.

Gertler et al. (2012) consider an analogous agency problem between bank managers (or inside equity holders) and (outside) shareholders. They retain the basic structure of Gertler and Kiyotaki (2010), in which each banker is a member of a particular household (serving as a model proxy for inside shareholders), but also allow banks to issue equity to other households. The agency problem puts an upper bound on the amount of equity finance, given the banker's personal net worth. In the model, bankers have an incentive to raise the maximum amount of funds, subject to the limit on obligations that they can commit to honor, in 
the markets for debt and equity. So this model corresponds to setting very high adjustment-cost parameters in our dividend-smoothing framework.

In Collard et al. (2012)—-henceforth CDDL_we articulate an alternative way of pinning down the capital structure of banks: prudential policy sets a minimum capital ratio and the tax advantage of debt finance (over equity finance) gives banks an incentive to rely on debt finance as much as they can. In CDDL we focus on different conceptual issues (we do not consider policy responses to liquidity shocks), but our framework is in sharp contrast to models with debt limits in that our banks can readily change their financial structure; they just find equity finance expensive.

Jermann and Quadrini's $(2009,2012)$ work on the nonfinancial business sector considers a tax distortion like the one in CDDL as well as adjustment costs as in the model of the present paper. The estimates in Jermann and Quadrini (2009) suggest that the tax distortion is the only relevant factor (the estimate of the dividend smoothing parameter is essentially zero), but the estimates in Jermann and Quadrini (2012) contradict this finding (suggest a positive dividend smoothing parameter).

Studying the nature and degree of frictions in the market for bank equity seems like an important topic for future research on quantitative models of monetary policy.

\section{CONCLUSIONS}

In this paper, we have added banks and frictions in the market for bank capital to the standard New Keynesian model. We have used this model to study the positive and normative implications of a shock to the demand for bank reserves. This shock serves to illustrate the effects of liquidity shocks of the type emphasized by Gertler and Kiyotaki (2010). The existence of an equity market friction matters significantly for the effects of this shock and the properties of optimal monetary policy. Our main finding is that in response to an increase in the banks' demand for liquidity, optimal monetary policy accepts a significant output contraction. This would not have been the case in the absence of the friction. Hence, monetary policy becomes less accommodating to liquidity shocks under equity market frictions. We also find that optimal policy (with or without the equity-market friction) involves large adjustments in the money supply, a property reminiscent of Poole's analysis. Consequently, restrictions on the quantity of money supplied by the central bank can carry significant welfare costs in times of financial turbulence. Also, the presence of financial frictions and liquidity shocks does not invalidate the well-known implication of the standard NK model that a simple interest-rate rule that targets inflation is close to the optimal policy. There is a caveat here, though: namely, that such a rule should target a measure of inflation that is relatively insensitive to financial shocks.

Adding a fiscal instrument that allows making transfers to banks serves to remove the equity-market friction in our model. That is, optimal policy with the 
two (fiscal and monetary) instruments in the presence of the friction leads to the same equilibrium that optimal monetary policy would implement absent the friction.

To be clear, some aspects of our results are likely to be sensitive to our modeling choices. In particular, the inflationary effects of financial shocks in our model arise in models that, like ours, include a cost channel of monetary transmission. The details of how the policy rate optimally responds to shocks could be different, for example, had we assumed that households (rather than producers of final goods) borrow from banks. The point that is robust, and our main point, is that optimal policy responses to a shock that affects the funding side of banks and the usefulness of a fiscal instrument depend on what we assume about frictions in the market for bank equity and other sources of funding. The main weakness of the present analysis lies in its specification of these frictions. We have no guidance from the existing literature for setting the parameters $\left(\Phi_{a}\right.$ and $\left.\Phi_{z}\right)$ that determine the severity of the funding frictions that banks face. If we set either parameter to zero, shocks to the funding side of banks will have no effect on the lending side. Extensions that would model these frictions in a more compelling fashion appear to us to be of high value added both from a positive and from a normative point of view, especially regarding the properties of jointly optimal fiscal and monetary policies.

\section{NOTES}

1. Because the standard New Keynesian (NK) model [e.g., Woodford (2003)] abstracted from money and banking, a rapidly growing literature introduced banks into models of monetary policy to address topical issues. Contributions include Gertler and Kiyotaki (2010), Hobijn and Ravenna (2010), Meh and Moran (2010), and Gertler and Karadi (2011), among others.

2. This was indeed the presumption of some economists [e.g., Mulligan (2008)] who argued against the U.S. bank-bailout plan informally, asserting that it was simply a transfer from taxpayers to the owners of banks.

3. Our impression, based on conversations with central bankers in the United States and Europe, is that banks argued against issuing new equity on the grounds that the equity premium was unreasonably large at the time, and recapitalization via the stock market would not be in the interest of current shareholders.

4. We adopt the dividend-smoothing specification of Jermann and Quadrini $(2009,2012)$ to capture these frictions.

5. In the corporate finance literature, the observation that managers smooth dividends goes back to Lintner (1956). Jermann and Quadrini (2012), drawing on earlier work, motivate it as a shortcut for agency problems associated with the equity payout.

6. In particular, dividends are smooth in the models of Gertler and Kiyotaki (2010) and Gertler and Karadi (2011), because banks only pay dividends when they are hit by a random exit shock (which hits the same fraction of banks each period).

7. Fernández-Villaverde (2010) also addresses the issue of fiscal and monetary policies in the presence of financial frictions, but from a very different perspective: in his model, the financial frictions do not apply to a banking sector, fiscal policy consists in government expenditures financed by distortive taxes and public debt, and fiscal and monetary policies are not optimal.

8. Securitization is equivalent to risk-free debt in our model because the aggregate default rate is predictable and there are no information asymmetries in the model. In equilibrium, $a_{t}$ will consist of 
bank liabilities (we can think of it as commercial paper or securitized loans) because we will assume the government maintains a balanced budget.

9. Interpreting $\delta_{t}$ in terms of default is obviously stylized, and our discussion will not depend on this shock in a substantive way (it only affects our numerical welfare calculations later). The shock will serve two purposes in our model: it makes banking costly, and it leads to a distinction between the price index for intermediate goods and the price of final goods. We could replace the shock with a specification of banking costs and a productivity shock in the final-goods sector.

10. The retailers need funding in our model's financial exchange to buy intermediate goods (and the sellers of these goods use the funds to pay wages and dividends). As usual, our assumption that these funds are borrowed from banks (rather than households) amounts to endowing banks with some monitoring skills that are necessary to avoid fraud, etc.

11. The only reason we assume banks have market power is to remove the period-by-period zero-profit condition that would be implied by a perfectly competitive banking sector. We could not have random taxation (or fiscal transfers) in the banking sector while satisfying a zeroprofit condition at every date. Nor could we model dividend smoothing if our banks made zero profits.

12. More specifically, final goods producers choose their portfolio of differentiated loans $\left(l_{i, t}\right)_{1 \leq i \leq n_{l}}$ to maximize the Dixit-Stiglitz aggregator $\left[\sum_{i=1}^{n_{l}} l_{i, t}^{s_{l}}\right]^{\frac{1}{s_{l}}}$, where $s_{l} \equiv \frac{\gamma_{l}-1}{\gamma_{l}}$, subject to a budget constraint of type $\sum_{i=1}^{n_{l}}\left(1+R_{i, t}^{L}\right) l_{i, t} \leq K^{l}$, whereas households choose their portfolio of differentiated deposits $\left(d_{i, t}\right)_{1 \leq i \leq n_{d}}$ to minimize the Dixit-Stiglitz aggregator $\left[\sum_{i=1}^{n_{d}} d_{i, t}^{s_{d}}\right]^{\frac{1}{s_{d}}}$, where $s_{d} \equiv \frac{\gamma_{d}+1}{\gamma_{d}}$, subject to a profitability constraint of type $\sum_{i=1}^{n_{d}}\left(1+R_{i, t}^{D}\right) d_{i, t} \geq K^{d}$.

13. The borrowing limit would represent a kink making the marginal cost infinite at $a^{*}$.

14. But these bonds are implicitly present because our monetary authority trades them in open market operations.

15. We do not pursue quantitative results because our stylized model cannot match basic features of banking sector data anyway. For example, in U.S. data, deposits and bank loans are three to four times the size of quarterly consumption; in our model, consumption of "deposit goods" has to be smaller than total consumption, and loans have to be about as large as output.

16. Setting $\Phi_{z}$ and $\Phi_{a}$ larger than 0.25 would make banks less willing to adjust dividend payments and borrowing (securitization); this would make the effects of the liquidity shock larger under all the policies we consider in further discussion, but it would not affect the qualitative features or comparisons across policies that we will highlight.

17. We deactivate this shock throughout, except when we use impulse responses to highlight its transmission mechanisms.

18. More precisely, the standard deviation $\sigma_{\delta}$ of the default shock innovation is set so that a variable having a Gaussian probability distribution with mean zero and variance $\sigma_{\delta}^{2}\left(1+\rho_{\delta}^{2}+\rho_{\delta}^{4}+\rho_{\delta}^{6}\right)$ exceeds $\ln (2.88)-\ln (0.86)$ with probability $1 / 320$, where $\rho_{\delta}=0.9$ denotes the inertia in the default shock.

19. We conduct our analysis in the neighborhood of the steady state because, as mentioned at the beginning of the Introduction, we focus in this paper on the effects of financial frictions on the transmission of liquidity shocks in "normal times."

20. More precisely, the optimal steady state deflation rate is about $0.04 \%$ per quarter, in all versions of our model.

21. Some of the small responses in our IRFs also reflect general-equilibrium interactions that we do not highlight in the text. For example, after an increase in demand for reserves, the interest rate on deposits rises (because banks try to tap the deposit market more as their balance sheets tighten) and consumers switch from buying cash goods to buying deposit goods. This reduces household demand for money.

22. For a general discussion of the cost channel, see Christiano et al. (2010).

23. More precisely, we set nominal money growth equal to 1.15 times the steady-state inflation rate minus 0.15 times the last quarter's inflation rate. We need this negative response to lagged inflation to get determinacy in our model. 
24. This reflects a small general-equilibrium interaction. The contraction of output reduces the demand for loans, and banks compete to attract borrowers by cutting the interest rate on loans.

25. We suspect that the small contraction in consumption reflects the wealth effect of the decrease in bank profits.

26. The only qualitative differences (which are quantitatively small) are in the responses of inflation in the price of intermediate goods and the policy rate-optimal monetary policy raises the rate when the liquidity shock arises from a shock that hampers securitization. This is because printing money is not an effective way to deal with a liquidity shock that does not directly increase money demand.

27. Most applications involve additional model features that turn the inequality constraint, implied by the debt limit, into an equality constraint. We worked instead with a smooth version to avoid solving a Ramsey problem subject to an inequality constraint.

\section{REFERENCES}

Barth, Marvin J., III and Valerie A. Ramey (2001) The cost channel of monetary transmission. In Ben S. Bernanke and Kenneth Rogoff (eds.), NBER Macroeconomic Annual, pp. 199-239. Cambridge, MA: MIT Press.

Chari, V.V., Lawrence J. Christiano, and Patrick J. Kehoe (1991) Optimal fiscal and monetary policy: Some recent results. Journal of Money, Credit and Banking 23, 519-539.

Christiano, Lawrence J., Martin Eichenbaum, and Charles L. Evans (2005) Nominal rigidities and the dynamic effects of a shock to monetary policy. Journal of Political Economy 113(1), 1-45.

Christiano, Lawrence J., Mathias Trabandt, and Karl Walentin (2010) DSGE models for monetary policy analysis. In Benjamin M. Friedman and Michael Woodford (eds.), Handbook of Monetary Economics, pp. 285-367. Amsterdam: Elsevier North-Holland.

Collard, Fabrice and Harris Dellas (2005) Poole in the New Keynesian model. European Economic Review 49(4), 887-907.

Collard, Fabrice, Harris Dellas, Behzad Diba, and Olivier Loisel (2012) Optimal Monetary and Prudential Policies. Bank of France working paper 413.

Correia, Isabel, Juan Pablo Nicolini, and Pedro Teles (2008) Optimal fiscal and monetary policy: Equivalence results. Journal of Political Economy 116(1), 141-170.

Fernández-Villaverde, Jesús (2010) Fiscal policy in a model with financial frictions. American Economic Review, Papers and Proceedings 100(2), 35-40.

Gerali, Andrea, Stefano Neri, Luca Sessa, and Federico M. Signoretti (2010) Credit and banking in a DSGE model of the Euro area. Journal of Money, Credit and Banking 42(S1), 107-141.

Gertler, Mark and Peter Karadi (2011) A model of unconventional monetary policy. Journal of Monetary Economics 58(1), 17-34.

Gertler, Mark and Nobuhiro Kiyotaki (2010) Financial intermediation and credit policy in business cycle analysis. In Benjamin Friedman and Michael Woodford (eds.), Handbook of Monetary Economics, pp. 547-599. Amsterdam: Elsevier North-Holland.

Gertler, Mark, Nobuhiro Kiyotaki, and Albert Queralto (2012) Financial crises, bank risk exposure, and government financial policy. Journal of Monetary Economics 59(S), S17-S34.

Hobijn, Bart and Federico Ravenna (2010) Loan Securitization and the Monetary Transmission Mechanism. Mimeo, Federal Reserve Bank of San Francisco, University of California-Santa Cruz, and HEC Montréal.

Jermann, Urban and Vincenzo Quadrini (2009) Financial Innovations and Macroeconomic Volatility. Mimeo, Wharton School of the University of Pennsylvania and University of Southern California.

Jermann, Urban and Vincenzo Quadrini (2012) Macroeconomic effects of financial shocks. American Economic Review 102(1), 238-271.

Khan, Aubhik, Robert G. King, and Alexander L. Wolman (2003) Optimal monetary policy. Review of Economic Studies 70, 825-860.

Kiyotaki, Nobuhiro and John Moore (1997) Credit cycles. Journal of Political Economy 105(2), 211-248. 
Levin, Andrew and David López-Salido (2004) Optimal Monetary Policy with Endogenous Capital Accumulation. Mimeo, Federal Reserve Board.

Lintner, John (1956) Distribution of incomes of corporations among dividends, retained earnings, and taxes. American Economic Review 46, 97-113.

Lucas, Robert E., Jr. (2003) Macroeconomic priorities. American Economic Review 93(1), 1-14.

Lucas, Robert E., Jr. and Nancy Stokey (1983) Optimal fiscal and monetary policy in an economy without capital. Journal of Monetary Economics 12(1), 55-93.

Meh, Césaire A. and Kevin Moran (2010) The role of bank capital in the propagation of shocks. Journal of Economic Dynamics and Control 34(3), 555-576.

Mulligan, Casey B. (2008) Is the Treasury impotent? Economists' Voice 5(7).

Poole, William (1970) Optimal choice of monetary policy instruments in a simple stochastic macro model. Quarterly Journal of Economics 84(2), 197-216.

Ravenna, Federico and Carl E. Walsh (2006) Optimal monetary policy with the cost channel. Journal of Monetary Economics 53, 199-216.

Woodford, Michael (2003) Interest and Prices: Foundations of a Theory of Monetary Policy. Princeton, NJ: Princeton University Press. 